\title{
Transatlantica
}

Revue d'études américaines. American Studies Journal

\section{Margaret Olin, Touching Photographs}

Chicago and London, The University of Chicago Press, 2012

\section{Angeliki Tseti}

\section{CpenEdition}

Journals

Édition électronique

URL : https://journals.openedition.org/transatlantica/6694

DOI : 10.4000/transatlantica.6694

ISSN : 1765-2766

Éditeur

Association française d'Etudes Américaines (AFEA)

Édition imprimée

Date de publication : 31 décembre 2013

Référence électronique

Angeliki Tseti, « Margaret Olin, Touching Photographs », Transatlantica [En ligne], 2 | 2013, mis en ligne le 30 avril 2014, consulté le 01 février 2023. URL : http://journals.openedition.org/transatlantica/6694 ; DOI : https://doi.org/10.4000/transatlantica.6694

Ce document a été généré automatiquement le 1 février 2023.

\section{c.) (i) (2)}

Creative Commons - Attribution - Pas d'Utilisation Commerciale - Pas de Modification 4.0 International - CC BY-NC-ND 4.0

https://creativecommons.org/licenses/by-nc-nd/4.0/ 


\title{
Margaret Olin, Touching Photographs
}

\author{
Chicago and London, The University of Chicago Press, 2012
}

\section{Angeliki Tseti}

\section{RÉFÉRENCE}

OLIN, Margaret, Touching Photographs, Chicago and London, The University of Chicago

Press, 2012, 273 pages, ISBN - 13: 978-0-226-62646-8, ISBN - 10: 0-226-62646-6, $30 €$

1 "In teaching us a new visual code", Susan Sontag wrote almost forty years ago, "photographs alter and enlarge our notions of what is worth looking at and what we have a right to observe. They are a grammar and, even more importantly, an ethics of seeing ... we can hold the whole world in our heads-as an anthology of images" (On Photography, 3). Margaret Olin's inspired new book constitutes a groundbreaking contribution to the theory of photography and the visual, which, while acknowledging photography's function as evidence and representation of the real, insightfully supplements Sontag's observations on photography by embarking on the premise that tactility is as inherent to the photograph as visuality and by highlighting the medium's potential to "participate in and create relationships and communities" (15). To this end, Olin employs the metaphor of touch, traces its "polarity" with vision in perceptual theory (7), and shifts the emphasis on the photograph's physical presence in order to emphasize the medium's social dimension and its role in establishing individual interaction, communal inter-relation, emotional identification or empowerment.

2 The delineation of photography's active participation in the construction of social affinities and interpersonal relationships necessitates a trajectory that moves beyond academic discussions on the "ontology of photographic or photo-historical methodology" (17). Touching Photographs, therefore, consists of six chapters which simulate a wandering over a wide variety of photographic practices, ranging from the 1920s and 1930s-and James Van Der Zee's Harlem funeral portraits or James Agee and Walker Evans's photo-text Let Us Now Praise Famous Men - to the more recent examples of photographic memorialization practices of the exhibitions organized around the 
photographs of 9/11 or Susan Meiselas' aka Kurdistan web project, and the Abu Ghraib prison photographs. During these wanderings, Olin also re-visits canonical texts, such as Roland Barthes's Camera Lucida, or W. G. Sebald's fiction, and complements the numerous photographic reproductions of the projects discussed with snapshots taken from her personal archives. This diverse material is organized around questions of agency on the part of the photographer/author, or the various collectors and institutions responsible for the dissemination and publication of the photographs, and consistently raises the question of how "photographs act rather than represent" (17), in a prose that is eloquent and engaging, rich in examples and details, but without sacrificing the depth of analysis.

3 The book's first three chapters discuss predominantly the establishment of interpersonal relationships between the photographic subject and the viewer. The inaugural "It is Not Going to Be Easy to Look into Their Eyes", turns to Agee and Evans's collaboration in Let Us Now Praise Famous Men to investigate the concept of the gaze and its employment as a means of merging the journalistic documentary form and the artistic photographic text, with the intent to raise public awareness and, thus, promote social activism. Olin provides an insightful analysis of the ways the device of the gaze permeates not only Evans's photographs of the sharecroppers, but also Agee's narrative, and suggests that it is precisely the return of the gaze that results in the construction of a "shared subjecthood" (30) between the photographed subject and the viewer/reader of the project.

Chapter 2, "Roland Barthes's 'Mistaken' Identification" is, without a doubt, one of the salient chapters of this book, as it comprises a powerful enactment of Olin's concept of the photograph as "performative index" which the author derives from Charles Sanders Peirce's formulation of the photographic index. The "performative index" is defined as performing "a relation that may not depend on resemblance" (6), may "lie not in the relation between the photograph and its subject but in the relation between the photograph and its beholder", (69) on the mental associations and interrelations the photograph triggers. Here, Olin engages in a brilliant reading of Barthes's Camera Lucida, founded on memory's ability to deceive, and proclaims that the concept of the punctum (the "pricking" or touching detail that affectively connects the viewer with the photographic object) may be displaced or "misidentified" and be found to reside beyond the photograph, or even beyond the visual realm, in the pictures lying in the beholder's memory, in the viewer's needs and desires.

5 The subject of displacement is further elaborated and discussed in Chapter 3, through an investigation of the intertextual threads that connect the work of W. G. Sebald and Hugo von Hofmannsthal; "From One Dark Shore to the Other", in fact, seems to be quite debatable and perhaps the weakest contribution to this collection of essays. Olin's opting for a critical analysis that does not take into consideration the readings informed by the theories of Trauma Studies-and that, consequently, results in arbitrary, precarious argumentation-notwithstanding, the treatment of these authors' work and the development of the text may pose considerable obstacles for the readers who are not familiar with Sebald or von Hofmannsthal.

6 "Putting Down Photographic Roots in Harlem", the fourth chapter of the book, widens the aperture to discuss photographic acts and projects that address interactions with larger groups and foster the creation of "imagined" communities. James Van Der Zee's work is portrayed as one such example of the promotion of a feeling of entwinement 
between total strangers, generated through sharing a common fate and advancing the construction of a common cultural milieu. Here, Olin juxtaposes, compares and contrasts Van Der Zee's studio portraits to the photographic projects of Cecil Beaton and August Sander, and traces their connection to Steichen's famous exhibition The Family of Man, and Michael Lesy's Wisconsin Death Trip, to delineate the ways the artist's work achieved precisely such a "construction of a collective face" (106).

7 The exploration of Van Der Zee's work and his contribution to the formation of a communal identity also raises the issue of authenticity as largely dependent on the photographer's gaze and experience, which is extensively taken up in Chapter 5, "Looking through Their Eyes", where Olin addresses projects intended "to overcome the power of photographer over the subject, ultimately to transform subjects into photographers or authorities over their own representation" (132). The author considers the use of disposable cameras in photographic "empowerment projects", such as Nicholas Kristof's "Disposable Cameras for Disposable People", or the movement often referred to as "Kids with Cameras", and focuses on the Chiapas Photography Project as a paradigm of a truly empowered kind of photography, where the viewer is asked not to simply look at the subject, but to "look through someone else's eyes, to identify with the photographer" (140). Within the same context, Olin also discusses Susan Meiselas' akaKURDISTAN, an ongoing, interactive, Internet-based project that began as a component of an exhibition entitled "Kurdistan: In the Shadow of History", followed by a book of the same title, and is dedicated to the promotion of Kurdish nationalism by way of developing a "visualized community" which affirms its presence via interviews, personal stories, photographs and a collage of reproduced documents.

8 The argument traversing Touching Pictures, that a photograph may allow a community to form around it, culminates in the final chapter of the book, "Five Stories of 9/11", where Olin explores the importance of inter-subjective experience in the face of historic catastrophe by discussing photographic activity, in the aftermath of the World Trade Center attacks, performed by the media, by well-known photographers in the art world, but also in the exhibitions staged around the amateur, personal photographs of New Yorkers. Although Olin's personal involvement occasionally results in a particularly emotionally-heightened tone and, thus, in formulations that may seem exaggerated or forced, this chapter beautifully recapitulates the argumentation permeating the previous parts of the book and, more importantly, introduces the author's concept of "basking" or immersing oneself in the photograph, rather than examining it, which does not offer the knowledge a viewer would obtain from an accompanying text or caption, yet bestows a therapeutic effect and catalytically contributes to the formation of cultural affiliations and collective identities.

All in all, Touching Pictures is a fascinating promenade in the photographic universe, which is not only meticulously elaborated but also masterfully constructed. Besides offering an essential, thoroughly researched close reading of the texts-both verbal and visual-she chooses to include in her material, Olin has produced a book that enacts her argument in the most eloquent way, in the subtle, yet demonstrative interrelationships established between the different projects presented. A note should also be made on the quality of the publication, whose aesthetics and layout enhance the author's free-flowing prose and unhindered articulation. In effect, while critically engaging with photography's multivalence, Touching Pictures constitutes a wonderfully 
stimulating and thought-provoking exercise in the lasting cultural and social impact of the photograph and an important contribution to the medium's reinstatement as a powerful generator of communal affiliation and political interaction.

\section{AUTEURS}

\section{ANGELIKI TSETI}

University of Athens/Université Paris Diderot 